This is a pre-copyedited, author-produced version of an article accepted for publication by Elsevier in Utilities Policy on 2016 following peer review, available online: https://doi.org/10.1016/j.jup.2016.04.012.

Utilities Policy 43 (2016) $117-12$

\title{
Water affordability issues in developed countries - The relevance of micro approaches
}

\section{Rita Martins ${ }^{\text {a, }}$, , Carlota Quintal ${ }^{\mathrm{b}}$, Luís Cruz ${ }^{\mathrm{a}}$, Eduardo Barata ${ }^{\mathrm{a}}$}

'GEMF/CeBER and Faculty of Economics, Universioy of Coimbra Av, Dias da Silva 165, 3004-512. Pornugal

${ }^{\circ}$ CESUC,CEBER and Foculty of Economias, University of Coimbra. Ak. Dias da Silva, 165, 3004-512, Portugal

A RTICLE IN FO

\section{Articie history:}

Received II December 201.

Received in revised form

II March 2016

Accepted 3 April 2016

Available online 1 June 2016

J日 chssification:

105

025

R20

Keywords:

Water affordability

Economic regulation

Micro data
A B S T R A C T

In developed countries, water affordability issues are regarded as a non-significant problem. This pape analyses the prevalence of affordability problems at household level and the determinants that might affect their occurrence. From a questionnaire-based survey. Portuguese household level data are used to show that average measures can mask affordability issues for substantial proportions of the low income groups. Findings also indicate that to tackle affordability problems more successfully. special tariff schemes should consider household income, size (large families) and composition (children in poorer households). 


\section{Introduction}

Water is at the core of sustainable development goals and it is critical for human well-being, economic prosperity and the preservation of environmental capital. Significantly, for the UN in 2014 this discussion on the role of water for the achievement of all three dimensions of sustainable development - social, economic and environmental - indicates affordability as a key challenge that needs to be addressed, especially in non-developed and developing countries. This paper questions the implicit assumption that affordability issues can be considered as a solved or a non-significant problem in developed countries. This study assesses micro water affordability (using primary disaggregated household level data) to show that macro (average) measures can mask serious affordability issues for substantial proportions of the more vulnerable households. In fact, average ratios do not fully reflect differences between households in terms of their consumption needs (related to household size) and income.

The paper begins with a brief summary of the most recent developments towards a worldwide commitment to water affordability, taking into account both the contributions to the human rights dimension and the role of regulation and public policies (Section 2). This review further considers the multiple approaches to define the critical threshold for water to be affordable, by comparing the benchmarks recommended by major international organisations with the relevant scientific literature on the empirical assessment of water affordability (Section 3).

This research has three main empirical purposes. First, to analyse the prevalence of affordability problems, using micro data. Second, to implement a sensitivity analysis to re-examine the prevalence of affordability problems, using the minimum and maximum thresholds adopted by major international organisations. Third, to determine the main characteristics associated with the occurrence of affordability issues, using multiple logistic regression analysis. Ultimately, we aim to empirically illustrate the importance of using micro data to assess whether water affordability concerns should be reinforced/redirected by taking the case of Portuguese households as an example. The remainder of the paper is structured as follows. Section 2 presents a short chronology of the main milestones regarding the recognition of water affordability as a crucial goal. Section 3 provides a brief review of the thresholds usually considered by national and international organisations. Section 4 presents the data and methodology. The main results are presented and discussed in Section 5. Section 6 concludes.

\section{Pathways for a worldwide commitment to water affordability}

Water and sanitation services are essential for human life, for health, for dignity and for economic prosperity. Water affordability is now being recognised as an official target, or even a 
legal requirement, in an increasing number of countries (Smets, 2009). However, despite the consensus on the principles at stake, an effective worldwide commitment towards water affordability is still in its early stages. Significantly, the progress already achieved illustrates both the contribution of a human rights dimension and the role of regulation and public policy.

The human 'right to water' as the right to have access to the water required to satisfy basic human needs was first established in Argentina at the 1977 United Nations (UN) Water Conference. But water affordability emerged as a general principle only in 1992. In the Dublin Statement on Water and Sustainable Development (Agenda 21), later approved at the UN Conference on Environment and Development, the term 'access' was finally explicitly recognised as also involving economic accessibility, i.e., the right to have access to water at an affordable price. In 2002, the UN Committee on Economic, Social and Cultural Rights adopted General Comment No. 15. This confirms the right to water in international law and defines it as the right of everyone "to sufficient, safe, acceptable, physically accessible and affordable water for personal and domestic uses". At the European Union (EU) level, Protocol (No. 9) to the Treaty of Lisbon (2007) on services of general interest formally introduced the concept of affordability in EU law as: "The shared values of the Union in respect of services of general economic interest include in particular: (...) a high level of (...) affordability, equal treatment and the promotion of universal access and of user rights". In 2014, the UN General Assembly unanimously adopted a Resolution agreeing on a set of Sustainable Development Goals, including one dedicated to water, with targets for universal access to drinking water, sanitation and hygiene for individual households and for health care centres and schools, and for the safe management of wastewater, including its treatment, re-use and recycling. The discussion on the role of water, sanitation and hygiene in achieving sustainable development in the World Water Development Report 2015 (UNESCO, 2015) specifies affordability as one of the key challenges that needs to be addressed.

Meanwhile, the Lisbon Charter for Good Practices in Public Policy and Regulation of Water Supply Services and Wastewater Sanitation (IWA, 2015: 8), recently adopted by the International Water Association, and recognised in the Ministerial Declaration resulting from the $7^{\text {th }}$ World Water Forum, explicitly emphasises the principle of "maintaining a fair balance between the affordability of the service provided and the level of cost recovery that ensures sustainability" as one of the principles for good public policy and effective regulation. Indeed, consumer protection, in particular the promotion of affordable prices, is a critical duty of water regulators, regardless the regulatory regime. 
To sum up, water affordability is a central element to access to water and to guaranteeing the human right to water and wastewater services.

\section{Water affordability benchmarks and empirical assessment}

Water affordability has commonly been measured as the share of household income spent on water charges (e.g. Fitch and Price, 2002; Sawkins and Dickie, 2005; Reynaud, 2010). In general, in industrialized countries, water charges represent around $1.1 \%$ of the income of households with median disposable income, while for poor households it represents approximately $2.6 \%$ (Smets, 2009).

Households paying an amount for water that exceeds an affordability threshold are often deemed to be facing affordability problems. But there is no consensus on establishing a limit for a water affordability that could be identified as: the affordability benchmark (Fankhauser and Tepic, 2007), the threshold of affordability (OECD, 2003) or the target ratio (Gawel et al., 2011). Further, it has been argued that only those uses corresponding to the satisfaction of domestic essential needs - i.e. the water consumption needed to maintain acceptable or minimum living standards - should be considered in affordability assessments (Reed, 2005; Martins et al., 2013a). Nevertheless, international guidelines have not been suggested by the relevant institutions (Howard and Bartram, 2003; Martins et al., 2013b) and thus its operationalization is so far rather general (e.g., the water consumption quantity that is price-inelastic).

Table 1 summarises the benchmarks considered by the most relevant water governance organisations for measuring the threshold for the water services affordability ratio (AR).

Table 1 - Benchmarks used in measuring water affordability

\begin{tabular}{|c|c|}
\hline Water governance relevant institutions & Threshold (AR) \\
\hline Asian Development Bank & $5 \%$ \\
\hline ERSAR (Portugal) & $3 \%$ \\
\hline OECD & $3 \%$ \\
\hline International Water Association (IWA) & $3 \%$ \\
\hline OECD (in Eastern Europe, Caucasus, and Central Asian countries) & $\begin{array}{c}4 \% \\
\text { (for poor families) }\end{array}$ \\
\hline United Kingdom Government & $\begin{array}{c}3 \% \\
\text { (for the lowest income } \\
\text { decile) }\end{array}$ \\
\hline United Nations Development Program (UNDP) & $3 \%$ \\
\hline World Bank & $2-2,5 \%$ \\
\hline
\end{tabular}

Source: Adapted from Fankhauser and Tepic (2007)

Despite the differences in the thresholds, Table 2 shows that a 3\% AR is often considered in the literature for water services. 
Table 2 - Literature review on water affordability empirical assessment

\begin{tabular}{|c|c|c|c|c|}
\hline Author (year) & $\begin{array}{l}\text { Services } \\
\text { considered }\end{array}$ & Country & $\begin{array}{l}\text { Threshold } \\
\text { (AR) }\end{array}$ & Main Results \\
\hline $\begin{array}{l}\text { Carvalho et al. } \\
\qquad(2010)\end{array}$ & $\begin{array}{l}\text { Water and } \\
\text { wastewater }\end{array}$ & Portugal & $3 \%$ & No macro affordability issues. \\
\hline ERSAR (2010) & $\begin{array}{l}\text { Water and } \\
\text { wastewater }\end{array}$ & Portugal & $3 \%$ & $\begin{array}{l}\text { No affordability issues on average. } \\
\text { Macro AR<3\% (even for the lowest income decile). } \\
\text { Potential micro-affordability problems. }\end{array}$ \\
\hline $\begin{array}{l}\text { Fankhauser } \\
\text { and Tepic } \\
\text { (2007) }\end{array}$ & $\begin{array}{l}\text { Water } \\
\text { Electricity } \\
\text { Gas }\end{array}$ & $\begin{array}{c}\text { Central and } \\
\text { Western Europe } \\
\text { and Former } \\
\text { Soviet Union } \\
\end{array}$ & $\begin{array}{l}5 \% \\
10 \% \\
10 \%\end{array}$ & $\begin{array}{l}\text { No affordability issues on average. } \\
\text { Higher AR for low income households. }\end{array}$ \\
\hline $\begin{array}{c}\text { Fankhauser et } \\
\text { al. (2008) }\end{array}$ & $\begin{array}{c}\text { Electricity, gas, } \\
\text { water, } \\
\text { telecom }\end{array}$ & Ukraine & $\begin{array}{c}20 \% \\
\text { (utilities) }\end{array}$ & $\begin{array}{l}\text { Social support not correctly targeted to diminish } \\
\text { affordability problems. } \\
\text { Variable coverage ratio among regions. }\end{array}$ \\
\hline $\begin{array}{l}\text { García- } \\
\text { Valiñas, et al. } \\
\quad(2010)\end{array}$ & Water & Spain (South) & $3 \%$ & $\begin{array}{c}\text { No affordability issues for basic quantities. } \\
19 \text { (out of } 300 \text { ) municipalities with AR } \\
\text { from } 3 \% \text { to } 5 \%\end{array}$ \\
\hline $\begin{array}{l}\text { Gawel et al. } \\
\qquad(2011)\end{array}$ & $\begin{array}{c}\text { Water } \\
\text { Wastewater }\end{array}$ & Mongolia & $\begin{array}{l}3 \% \\
2 \%\end{array}$ & $\begin{array}{l}\text { Physical access and poverty are two simultaneous } \\
\text { problems. } \\
\text { Potential affordability issues. }\end{array}$ \\
\hline $\begin{array}{l}\text { Mahmood } \\
\text { and Jing } \\
(2008)\end{array}$ & $\begin{array}{l}\text { Water and } \\
\text { wastewater }\end{array}$ & New Zealand & $3 \%$ & $\begin{array}{l}\text { The lowest income household group paid } 3.6 \% \text { of } \\
\text { their income on water and sewerage services }\end{array}$ \\
\hline $\begin{array}{l}\text { Martins et al. } \\
\text { (2013a) }\end{array}$ & Water Supply & Portugal & $2 \%$ & $\begin{array}{l}\text { No macro affordability concerns. } \\
\text { AR varies considerably across municipalities. }\end{array}$ \\
\hline $\begin{array}{l}\text { Miniaci et al. } \\
\qquad(2008)\end{array}$ & $\begin{array}{l}\text { Water } \\
\text { Gas } \\
\text { Electricity }\end{array}$ & Italy & $\begin{array}{c}1,8 \% \\
4,2 \% \\
3 \% \\
\end{array}$ & $\begin{array}{c}\text { Generally, there are no affordability issues. } \\
\text { For survival quantities, } 5.9 \% \text { of Italian households } \\
\text { have affordability issues. }\end{array}$ \\
\hline $\begin{array}{c}\text { Reynaud } \\
(2010,2006)\end{array}$ & Water & France & $3 \%$ & $\begin{array}{l}4.3 \% \text { of the French households spend more than } 3 \% \\
\text { of their income on water charges. Water affordability } \\
\text { is an important issue for poor households and for } \\
\text { single parent families. } \\
\text { Impact of private participation: not helping the poor. }\end{array}$ \\
\hline $\begin{array}{l}\text { Sawkins and } \\
\text { Dickie (2005) }\end{array}$ & $\begin{array}{l}\text { Water and } \\
\text { wastewater }\end{array}$ & UK & $3 \%$ & $\begin{array}{l}\text { Affordability issues are decreasing } \\
\text { Indebtedness is increasing }\end{array}$ \\
\hline $\begin{array}{l}\text { Wang, et al. } \\
\qquad(2010)\end{array}$ & $\begin{array}{l}\text { Water and } \\
\text { wastewater }\end{array}$ & China & $5 \%$ & $\begin{array}{l}\text { Water price increases are viable if poorer households } \\
\text { are subsidised. Willingness to pay > current price. }\end{array}$ \\
\hline
\end{tabular}

Table 2 shows that the significance of water affordability challenges has different degrees and intensities in different parts of the world. Although some studies acknowledge affordability of water services as a continuing concern (Stern and Mirrlees, 2012), affordability issues have consistently been seen as a solved or a non-significant problem in developed countries. Indeed, a large majority of water affordability studies based on macro assessments indicate no affordability problems, on average (see, e.g., ERSAR, 2010; Fankhauser and Tepic, 2007; Garcia Valiñas et al., 2010; Martins et al., 2013a; Miniaci et al., 2008).

However, some of these studies do reveal potential problems for specific groups of the population, particularly poorer households and single parent families. In this regard, evidence for Portugal based on the AR for different water consumption scenarios of representative average household size and income by municipality shows that, if we take the mean income of the poorest households nationwide, the water charges raise affordability concerns in an 
important number of municipalities, even for low water consumption levels (Martins et al., 2013a).

The previous findings support the argument that macro affordability analysis provides only a general and often misleading picture of the issue. Therefore the assessment of water services affordability should be supplemented with an analysis of micro affordability figures (Barraqué, 2011), particularly in the case of the most vulnerable households. These concerns are reinforced in the present context of economic and financial constraints.

\section{Data and Methodology}

This section introduces the data and the main methodological options used to attain our research goals. As disaggregated household level data is not available from national official statistics, primary data was collected from a household sample of residential users in mainland Portugal by means of a questionnaire-based survey performed in 2012. The random sampling framework made use of a complete telephone list of customers of 13 water utilities, with different management models and located in different Portuguese hydrographical regions. A total of 2,386 valid questionnaires were obtained which yielded detailed information on the characteristics of households and dwellings.

To calculate the observed micro AR, self-reported data on households' income was matched with actual records (provided by the 13 water utilities) on the monthly consumption and bills paid (in the prior 12 months) by the same customers. Besides identifying the type of management model of each water utility and considering the geographical differences between the municipalities in the sample, the dataset also reports on the hydrographical region to which the water services provider belongs, and indicates if it is on the coast or in an inland area of the country.

Following standard procedures in the literature, we looked into the prevalence of affordability problems using micro data by assuming that there are affordability problems when the water and wastewater AR is above the 3\% threshold. As in Reynaud (2010) and Miniaci et al. (2008), we calculated the prevalence of affordability problems (i.e., the percentage of families whose water and wastewater AR is $3 \%$ or higher); the AR was determined for all households, both for the whole sample and separately for each income group. The monthly charges actually paid by each household were computed based on the average of the bill paid over the last 12 months, according to the data provided by the water utility in the municipality where the residential customer lives. Concerning income, the questionnaire included 8 groups (cf. Table 3 ) and thus we took the mean value of the income group associated with the corresponding household. 
However, for the first income group (up to 500 euros), we adopted a different procedure given that the mean value of this income group (250 euros) was likely to underestimate the average monthly income of these households. We instead used the monthly income corresponding to the poverty line, which was 409 euros $^{1}$ in 2012 for Portugal (INE, 2014).

As commonly happens in Portuguese surveys, there were considerable missing values for the variable income. Thus, our final sample consisted of 1,958 observations (Table 4).

Next, we performed a sensitivity analysis to (re)assess the prevalence of affordability problems using the minimum (2\%) and the maximum (5\%) thresholds adopted by international organisations (e.g., as mentioned in Table 1, the US Environmental Protection Agency recommends a $2 \%$ threshold and the Asian Development Bank a 5\% one (PPIAF, 2012)).

Poorer households are expected to be more vulnerable to affordability issues, but from a policy perspective, it might be relevant to differentiate households based on other characteristics which may support some fine tuning of policy measures. Consequently, in the final part of the analysis we ran a multiple logistic regression in order to identify the main characteristics possibly associated with the occurrence (or absence) of household affordability problems, with a binary variable as the dependent variable (that takes the value 1 where the household faced affordability problems) (Agresti, 2013). This approach takes good advantage of the 'catastrophic spending analysis', frequently used in the health sector, where a household is said to have incurred catastrophic expenditure if its out-of-pocket healthcare payments amount to or exceed a threshold of its capacity to pay (Xu, 2005; O'Donnell et al., 2008).

To find the key characteristics that might be affecting water consumption, and hence water bills, we took water demand estimation literature into account (see, e.g., Arbués et al., 2005 and Worthington and Hoffman, 2008). Accordingly, we used two groups of independent variables from the demand-side in the regression analysis, these groups being household characteristics and dwelling characteristics. Based on previous evidence, large households and those with children tend to have higher consumptions while the presence of elderly household members tends to reduce water consumption. Based on the literature, education is positively correlated with income, thus being expected to decrease the risk of affordability issues. The dwelling characteristics are expected to affect the AR via consumption (and the corresponding water charges - numerator of the AR ratio) but might also reflect different wealth and income levels of the households (denominator of the AR ratio), in which case their impact on the occurrence

\footnotetext{
${ }^{1}$ To double check we also calculated the average household income using data from the Portuguese household budget survey 2010/2011 (for households whose monthly income was up to 500 euros) (INE, 2012). The mean value obtained was 424 euros.
} 
of affordability issues might generate opposite effects. For example, having a pool is expected to significantly increase water expenses, but only the richest households tend to have pools. Another group of variables relates to the supply side (management model ${ }^{2}$ and geographical location of the water utilities). The management model was included to try and test if the more market-oriented management models (concessions and delegations) have significant effects on affordability problems because of their potentially greater concern with cost recovery than with social issues, such as affordability objectives. Variables related to the geographical location were included to test for the potential influence of scarcity issues on tariffs and thus on affordability.

Table 3 shows the definitions of all the covariates.

Table 3 - Variables definition and descriptive statistics

\begin{tabular}{|c|c|c|c|}
\hline Variable & Definition & Mean & S.D. \\
\hline $\begin{array}{l}\text { Affordability Issues } \\
\text { (dependent variable) }\end{array}$ & $=1$, if $A R \geq 0.03$ & 0.160 & 0.367 \\
\hline \multicolumn{4}{|c|}{ Household characteristics } \\
\hline Elderly & $=1$, if the family has at least one elderly person $(65+)$ & 0.337 & 0.473 \\
\hline Children & $=1$, if the family has at least one child & 0.411 & 0.492 \\
\hline Large_family & $=1$, if large family ( $5+$ members) & 0.063 & 0.244 \\
\hline Basic & $=1$ if the respondent completed up to 9 years of schooling & 0.448 & 0.497 \\
\hline Secondary & $=1$ if the respondent completed secondary level of education & 0.272 & 0.445 \\
\hline Higher & $=1$ if the respondent completed a higher level of education & 0.279 & 0.447 \\
\hline \multicolumn{4}{|c|}{ Dwelling characteristics } \\
\hline Pool & $=1$, if the house has a pool & 0.040 & 0.184 \\
\hline Detached_house & $=1$, if the household lives in a semi-detached or detached house & 0.496 & 0.500 \\
\hline Zero_washmach & $=1$, if the household has neither washing machine nor dishwasher & 0.089 & 0.194 \\
\hline One_washmach & $=1$, if the household has one machine (washing or dishwasher) & 0.375 & 0.484 \\
\hline Two_or_more_washmach & $=1$, if the household has more than one machine & 0.542 & 0.498 \\
\hline \multicolumn{4}{|c|}{ Management model } \\
\hline Concession & $=1$, if the water utility is a concession & 0.127 & 0.333 \\
\hline Delegation & $=1$, if the water utility is a municipal (or an inter-municipal) firm & 0.169 & 0.374 \\
\hline Municipal_service & $=1$, if the water utility is a municipal service & 0.297 & 0.457 \\
\hline Municipalised_service & $=1$, if the water utility is a municipalised service* & 0.408 & 0.492 \\
\hline \multicolumn{4}{|c|}{ Geographical location } \\
\hline HR_Minho_Lima & $\begin{array}{l}=1, \text { if the household lives in the hydrographical region of Minho and } \\
\text { Lima }\end{array}$ & 0.086 & 0.281 \\
\hline HR_Douro & $=1$, if the household lives in the hydrographical region of Douro & 0.094 & 0.292 \\
\hline HR_Vouga_Mondego_Lis & $\begin{array}{l}=1, \text { if the household lives in the hydrographical region of Vouga, } \\
\text { Mondego and Lis }\end{array}$ & 0.210 & 0.407 \\
\hline HR_Tejo & $=1$, if the household lives in the hydrographical region of Tejo & 0.148 & 0.355 \\
\hline HR_Sado_Mira & $=1$, if the household lives in the hydrographical region of Sado and Mira & 0.216 & 0.411 \\
\hline HR_Guadiana & $=1$, if the household lives in the hydrographical region of Guadiana & 0.095 & 0.294 \\
\hline HR_Ribeiras_Algarve & $\begin{array}{l}=1, \text { if the household lives in the hydrographical region of Ribeiras do } \\
\text { Algarve }\end{array}$ & 0.151 & 0.359 \\
\hline Coastal_area & $=1$, if the household lives in a coastal area of the country & 0.729 & 0.444 \\
\hline
\end{tabular}

\footnotetext{
${ }^{2}$ See Martins et al. (2013b) and Pinto and Marques (2015a) for details on the institutional and regulatory framework of the Portuguese water industry, with reference to management models and discussion of tariff recommendations proposed by the national Water and Waste Services Regulation Authority (ERSAR).
} 
Our results are reported as odds ratios $(O R)$; the ratio of the odds of an event (affordability problems) occurring in one group compared to the odds of that event occurring in another group (Agresti, 2013). For example, if households without children are the reference category and $O R=1.5$, then households with children are 1.5 times more likely to face affordability problems than those without children; or, the risk of having affordability problems increases by $50 \%$ for households with children.

\section{Results and discussion}

Following the presentation of the data used and the main methodological options held to match our research goals, in this section we present and analyse the main results obtained.

Table 4-AR and the prevalence of affordability problems, by income groups

\begin{tabular}{|c|c|c|c|c|c|c|c|c|}
\hline \multirow{3}{*}{ Income Groups } & \multirow{3}{*}{$\begin{array}{c}\text { Average } \\
\text { monthly } \\
\text { bill }(€)\end{array}$} & \multirow{3}{*}{$\begin{array}{c}\text { Average } \\
A R \\
(\%)\end{array}$} & \multicolumn{6}{|c|}{ Households with: } \\
\hline & & & \multicolumn{2}{|c|}{$A R \geq 0.02$} & \multicolumn{2}{|c|}{$A R \geq 0.03$} & \multicolumn{2}{|c|}{$A R \geq 0.05$} \\
\hline & & & $n$ & $\%$ & $n$ & $\%$ & $n$ & $\%$ \\
\hline Income_up_€500 & 15.07 & 3.7 & 228 & 74.5 & 153 & 50.0 & 63 & 20.6 \\
\hline Income_ $€ 501-€ 1000 \quad(n=579)$ & 17.12 & 2.3 & 279 & 48.2 & 125 & 21.6 & 26 & 4.5 \\
\hline Income_€1,001-€1,500 ( $n=500)$ & 18.40 & 1.5 & 89 & 17.8 & 26 & 5.2 & 3 & 0.6 \\
\hline Income_€1,501-€2,000 (n=264) & 18.78 & 1.1 & 21 & 8.0 & 7 & 2.7 & 0 & 0 \\
\hline Income_ $€ 2,001-€ 2,500(n=157)$ & 20.17 & 0.9 & 6 & 3.8 & 2 & 1.3 & 1 & 0.6 \\
\hline Income_€2,501-€3,000 (n=57) & 21.33 & 0.8 & 1 & 1.8 & 0 & 0 & 0 & 0 \\
\hline Income_€3,001- $€ 3,500(n=42)$ & 21.75 & 0.7 & 1 & 2.4 & 0 & 0 & 0 & 0 \\
\hline Income_more_€3,500€ $(n=53)$ & 23.10 & 0.7 & 3 & 5.7 & 1 & 1.9 & 0 & 0 \\
\hline$(n=1,958)$ & 17.98 & 1.9 & 628 & 32.1 & 314 & 16.0 & 93 & 4.8 \\
\hline
\end{tabular}

As shown in Table 4, the macro affordability ratio for the whole sample (1.9\%) suggests the absence of affordability issues. The calculation of average ratios for income groups reveals differences between them, but the AR is above the $3 \%$ threshold only for the lowest income group. For example, the average AR of $2.3 \%$ in the $€ 501-€ 1000$ income group hides the detail that $21.6 \%$ households have an AR above the $3 \%$ threshold. Indeed, the analysis of the prevalence of affordability problems allows the assessment of this phenomenon's magnitude. It is striking that half of the households with a monthly income up to $€ 500$ face affordability problems (almost three-quarters if we consider the $2 \%$ threshold). The figures are also worrying for households with monthly income from $€ 501$ to $€ 1000$, being $21.6 \%$ and $48.2 \%$ for the $3 \%$ or the $2 \%$ threshold, respectively. For the income groups above $€ 1,000$ the prevalence of affordability issues decline significantly, which is logical given that water bills increase little in absolute values (second column of Table 4), and therefore have much less effect on the household income. 
Next, concerning the main characteristics possibly associated with the occurrence (or absence) of household affordability problems, the multiple logistic regression results are presented in Table 5.

Table 5- Association between risk factors and affordability problems

\begin{tabular}{|c|c|c|c|}
\hline Variable & Odds Ratio & $\mathrm{Cl} 95 \%$ & P-Value \\
\hline \multicolumn{4}{|c|}{ Household characteristics } \\
\hline Elderly & 1.487 & $1.118-1.977$ & 0.006 \\
\hline Children & 1.400 & $1.049-1.869$ & 0.022 \\
\hline Large family & 2.062 & $1.318-3.225$ & 0.002 \\
\hline Basic $^{a}$ & 0.940 & $0.695-1.272$ & 0.689 \\
\hline Secondary ${ }^{a}$ & 0.815 & $0.580-1.046$ & 0.240 \\
\hline \multicolumn{4}{|c|}{ Dwelling characteristics } \\
\hline Pool & 0.961 & $0.478-1.932$ & 0.911 \\
\hline Detached_house ${ }^{b}$ & 1.610 & $1.223-2.119$ & 0.001 \\
\hline One_washmach ${ }^{c}$ & 1.293 & $0.793-2.107$ & 0.303 \\
\hline Two_or_more_washmach ${ }^{c}$ & 0.539 & $0.332-0.874$ & 0.012 \\
\hline \multicolumn{4}{|c|}{ Supply side characteristics and geographical/environmental characteristics } \\
\hline Concession $^{d}$ & 0.216 & $0.045-1.046$ & 0.057 \\
\hline Delegation $^{d}$ & 0.161 & $0.033-0.782$ & 0.024 \\
\hline Municipal_service ${ }^{d}$ & 0.116 & $0.027-0.497$ & 0.004 \\
\hline RH_Minho_Lima ${ }^{e}$ & 0.098 & $0.020-0.482$ & 0.004 \\
\hline RH_Douro ${ }^{\mathrm{e}}$ & 0.115 & $0.006-2.391$ & 0.162 \\
\hline RH_Vouga_Mondego_Lis ${ }^{\mathrm{e}}$ & 0.098 & $0.022-0.431$ & 0.002 \\
\hline $\mathrm{RH}_{-}$Tejo ${ }^{\mathrm{e}}$ & 0.271 & $0.046-1.024$ & 0.054 \\
\hline RH_Sado_Mira ${ }^{e}$ & 0.624 & $0.321-1.212$ & 0.164 \\
\hline $\mathrm{RH}_{-}$Guadiana $^{\mathrm{e}}$ & 0.551 & $0.098-3.078$ & 0.497 \\
\hline Coastal-area & 0.962 & $0.190-4.874$ & 0.962 \\
\hline \multicolumn{4}{|c|}{$\begin{array}{l}\text { Reference categories: } \\
\quad{ }^{\mathrm{a}} \text { Higher education } \\
{ }^{\mathrm{b}} \text { Apartment } \\
{ }^{\mathrm{c}} \text { Zero washing machines } \\
{ }^{\mathrm{d}} \text { Municipalised service } \\
{ }^{\mathrm{e}} \text { Hydrographical Region of Ribeiras do Algarve } \\
\text { Nagelkerke } \mathrm{R}^{2}=0.126 ; \\
\text { Hosmer and Lemeshow Test }=0.524\end{array}$} \\
\hline
\end{tabular}

Table 5 shows that household characteristics are important predictors of the occurrence of affordability problems. Families with 5 or more members are twice more likely to face affordability problems than smaller families. Household composition also matters. Indeed, for the same type of household, having at least one child or one elderly person increases the risk of having affordability problems by $40 \%$ and $48 \%$, respectively. These results are in accordance with the demand estimation literature that has reported that households with more members and with children consume more water and thus face higher bills (see, e.g., Komives et al., 2005 and Whittington et al., 2015), particularly when increasing-block tariff systems are used ${ }^{3}$ (as it is the case in Portugal). The coefficient of the elderly variable is somehow unexpected, compared

\footnotetext{
${ }^{3}$ Unconditional price elasticity estimates, i.e., without constraining consumption to remain in a certain block after a price change, tend to be higher when discrete continuous choice models are used (Hewitt and Hanemann 1995; Rietveld et al. 2000; Miyawaki et al. 2011).
} 
with water demand estimation findings. In our case, the OR greater than 1 might be explained by the low level of income (retirement pensions) that elderly persons tend to have in Portugal. Concerning education, the effects are not statistically significant and are not as expected. However, one should notice that in our sample, the education variable corresponds to the level of education of the respondent, who is not necessarily the head of household.

Having a pool does not affect the risk of affordability problems, which probably derives from the reasons already exposed in the methodology section. Households living in semidetached/detached houses are more likely to spend $3 \%$ or more of their income on water and wastewater services. This result is understandable particularly taking into account that in rural areas living in semi-detached/detached houses is not a distinctive feature of richer households. Regarding the variable that indicates ownership of one washing machine, the OR is greater than one, but it is not statistically significant. On the other hand, having two or more washing machines decreases the risk of affordability problems by almost $50 \%$ (statistically significant). Again, this can be the result of opposing effects of dwelling characteristics, with the income effect outweighing the consumption effect.

Finally, focusing on supply-side factors and regarding the management model, households living in areas where the water utility is a concession, delegation or municipal service face lower risk of affordability problems compared with municipalised services, though the effect is statistically significant only in the last two cases, where the risk of affordability issues decreases more than $80 \%$.

These findings do not offer a clear pattern regarding the balance of the affordability and cost recovery objectives. However, this is not entirely surprising given the diversity of water utilities in Portugal in terms of their management models, size, vertical and the horizontal integration of services.

In terms of geographical area, households living in coastal areas are less likely to have affordability problems, but this effect is not statistically significant (tariffs tend to be higher in Portuguese coastal areas, but so is income). Hydrographical regions should roughly capture climate related or other issues of water scarcity. Compared with Ribeiras de Algarve (south), all regions have an odds ratios lower than one, suggesting a lower risk of affordability problems. The effects are more pronounced (in terms of both magnitude and statistical significance) for Minho/Lima (north) and Mondego/Vouga/Lis (centre).

Given the significant results regarding the prevalence of affordability problems in the lower income group, it is relevant to focus on this household subsample. Table 6 provides information on the profile of the households facing affordability issues. 
Table 6 - Households with $A R \geq 3 \%$ in the lower income group ( $n=133)$ : descriptive statistics

\begin{tabular}{|l|r|r|r|r|}
\hline \multicolumn{1}{|c|}{ Characteristics } & \multicolumn{1}{c|}{ Min } & \multicolumn{1}{c|}{ max } & \multicolumn{1}{c|}{ Mean } & \multicolumn{1}{c|}{ S.D. } \\
\hline Number of elderly persons & 0 & 2 & 0.5 & 0.69 \\
\hline Number of children & 0 & 5 & 0.6 & 1.01 \\
\hline Household size & 0 & 8 & 2.42 & 1.36 \\
\hline Average bill ( $€$ /month) & 12.29 & 32.40 & 19.13 & 5.45 \\
\hline Average consumption $\left(\mathrm{m}^{3} /\right.$ month) & 2.08 & 21.00 & 9.24 & 4.43 \\
\hline Affordability Ratio (\%) & 3.0 & 8.0 & 4.68 & 1.33 \\
\hline
\end{tabular}

For those households with affordability problems, the AR is, on average, 4.68 (i.e., more than $50 \%$ above the affordability threshold). Moreover, average household size within the lower income group (2.42) is approximately the same as the national one (2.54, according to Barata et al., 2015), its average water consumption $\left(9.24 \mathrm{~m}^{3} / \mathrm{month}\right)$ is slightly below the water consumption by the $€ 500-€ 1000$ and $€ 1000-1500$ income groups, and compares well with the $10 \mathrm{~m}^{3} /$ month usually considered by ERSAR as the reference average quantity consumed by Portuguese households. Therefore, it does not seem to be an issue of excessive consumption, but rather of consumption levels within inelastic quantities.

A logistic regression has been run to the Income_up_ $€ 500$ subsample, taking the household and dwelling characteristics into consideration (full results are available upon request). The results show that having at least one child (35\% of those households) increases the risk of affordability problems almost three times $(O R=2.792 ; p$-value $=0.003)$, well above the 1.4 figure for the whole sample (see Table 5). Furthermore, the OR for large households (7.5\% of the subsample) increases from 2.062 to 5.672 (although in this case with a 0.109 p-Value). Moreover, contrarily to the results for the whole sample, the OR for the variable elderly in this subsample suggests the expected lower affordability risk $(O R=0.628 ; p$-value $=0.108)$.

In Portugal, water tariffs proposed by utilities have to be approved by ERSAR and meet specific requirements regarding water affordability. In addition, special tariffs have been proposed for lower income households and large families. Nonetheless the criteria used to assess affordability are based on average figures. The results obtained in this study suggest that other measures such as special tariffs for low income households and for households with five or more members do not protect all households against problematic water affordability ratios. It is worth mentioning that these special tariffs must be applied for, and this procedure might constrain precisely the people who find it harder to deal with bureaucracy or feel uncomfortable about their poverty.

\section{Concluding remarks}

The empirical literature on water affordability analysis at the macro level in developed countries has largely agreed that access to water has been guaranteed under affordable conditions. This 
study assesses micro water affordability to investigate whether the evidence might be concealing affordability problems at the household level.

Our findings confirm that macro figures are not sufficient to evaluate water affordability and that even macro affordability ratios significantly below the accepted thresholds might coexist with a significant prevalence of households facing affordability issues, particularly for low income groups. It is striking the magnitude of affordability problems within these poorest households group. Accordingly, the methods and thresholds used to address affordability issues should be reviewed by academics, international organisations and/or water regulators.

Results also showed that large families and those with children are more exposed to affordability problems. While acknowledging that income (the AR denominator) is beyond the control of the utilities and regulatory authorities, they do nonetheless influence the water tariffs (the AR numerator). It is known that, taking into account the multiplicity of water tariff objectives, tariff schemes alone cannot achieve all the objectives at the same time and additional instruments need to be implemented (Pinto and Marques, 2015b). However, to tackle affordability problems more successfully, special tariff schemes should consider household income, size (large families) and composition (if there are children in the poorer households). E.g., households with five or more members, including children, and with less than a minimum income threshold per capita, could be exempted from paying water charges. Ultimately, this exemption can be applied instead only to the consumption level corresponding to the satisfaction of basic needs - e.g., 40 litres per person per day (Reed, 2005). Finally, there is still room for regulators and policy makers to monitor water services' affordability in developed countries, too, particularly when there are significant income distribution inequalities.

To sum up, this paper questions the conclusion that affordability issues are a non-significant problem in developed countries, particularly given the boundaries inherent to macro figures based analysis. Using Portuguese data, our empirical study supports the need for a more comprehensive analysis of these issues and the literature review exposed further potential concerns with water affordability in other developed countries, highlighting the need to be particularly alert to the potential problems faced by those more likely to suffer severe affordability restrictions.

\section{Acknowledgments}

This work has been undertaken under the Energy for Sustainability Initiative of the University of Coimbra and supported by the R\&D Projects "EMSURE - Energy and Mobility for Sustainable 
Regions" (CENTRO-07-0224-FEDER-002004) and "Pricing and behavioural responses in the water sector" (FCT PTDC/EGE-ECO/114477/2009).

\section{References}

Agresti, A. (2013) Categorical Data Analysis. $3^{\text {rd }}$ edition, Hoboken, NJ: John Wiley \& Sons.

Arbués, F.; Garcia-Valiñas, M.; Martínez-Espiñeira, R. (2003) 'Estimation of residential water demand: a state-of-the-art review'. Journal of Socio Economics, 32(1), 81-102.

Barata, E.; Martins, R.; Cruz, L.; Quintal, C. (2015) 'Affordability of water services in Portuguese Municipalities'. Revista Portuguesa de Estudos Regionais, 38, 37-46.

Barraqué, B. (2011), 'Is individual metering socially sustainable? the case of multifamily housing in France'. Water Alternatives, 4(2), 223-244.

Carvalho, P.; Simões P.; Marques, R. (2010), 'Acessibilidade económica e capacidade para pagar pelos serviços de água e de esgotamento sanitário em Portugal, Engenharia Sanitária e Ambiental, 15(4), 325-336.

ERSAR (2010) Acessibilidade económica aos serviços públicos de abastecimento de água para consumo humano e de saneamento de águas residuais urbanas em Portugal (Portuguese only). Report ERSAR n. 1/2010, Lisbon.

Fankhauser, S.; Rodionova, Y.; Falcetti, E. (2008) 'Utility Payments in Ukraine: Affordability, Subsidies and Arrears'. Energy Policy, 36(11), 4168-4177.

Fankhauser, S.; Tepic, S. (2007) 'Can poor consumers pay for energy and water? An affordability analysis for transition countries'. Energy Policy, 35(2), 1038-1049.

García-Valiñas, M., Martínez-Espiñeira, R.; González-Gómez, F. (2010) 'Affordability of residential water tariffs: Alternative measurement and explanatory factors in southern Spain'. Journal of Environmental Management, 91(12), 2696-706.

Fitch, M.; Price., H. (2002) Water poverty in England and Wales. Centre for Utility Consumer Law and Chartered Institute of Environmental Health Report.

Gawel, E.; Sigel, K.; Bretschneider, W. (2011) 'Affordability of water supply in Mongolia: Empirical lessons for measuring affordability'. UFZ Discussion Papers 9/2011, Helmholtz Centre for Environmental Research (UFZ).

Hewitt, J.; Hanemann, W. (1995) 'A Discrete/Continuous Choice Approach to Residential Water Demand under Block Rate Pricing'. Land Economics, 71(2), 173-192.

Howard, G.; Bartram, J. (2003) Domestic Water Quantity, Service Level and Health. World Health Organization, Geneva.

INE (2012) Household Budget Survey - 2010/2011 (Portuguese only). Statistics Portugal, Lisbon.

INE (2014) Statistics on Income and Living Conditions - 2013. Statistics Portugal, Lisbon.

IWA (2015) The Lisbon Charter - Guiding the Public Policy and Regulation of Drinking Water Supply, Sanitation and Wastewater Management Services. International Water Association. 
Komives, K.; Foster, V.; Halpern, J.; Wood, Q. (2005), 'Water, Electricity and the Poor: Who Benefits from Utility Subsidies?'. World Bank, Washington, DC.

Mahmood, B. and Jing, H. (2008) 'Affordability of Household Water and Sewerage Services in Waitakere City -A Case Study', WSAT $8^{\text {th }}$ Gulf Water Conference, Bahrain.

Martins, R.; Cruz, L.; Barata, E.; Quintal, C. (2013a) 'Assessing social concerns in water tariffs'. Water Policy, 15(2), 193-211.

Martins, R.; Cruz, L.; Barata, E. (2013b) 'Water Price Regulation: A Review of Portuguese Tariff Recommendations'. Public Organization Review, 13(2), 197-205.

Miniaci, R.; Scarpa, C.; Valbonesi, P. (2008) 'Measuring the affordability of basic public utility services in Italy'. Giornale degli Economisti e Annali di Economia, 67(2), 185-230.

Miyawaki, K.; Omori, Y.; Hibiki, A. (2011) 'Panel data analysis of Japanese residential water demand using a discrete/continuous choice approach'. Japanese Economic Review, 62(3), 365-386.

OECD (2003) 'Social Issues in the Provision and Pricing of Water Services'. OECD, Paris.

O'Donnell, O.; van Doorslaer, E.; Wagstaff, A.; Lindelow, M. (2008) Analyzing Health Equity Using Household Survey Data: A Guide to Techniques and Their Implementation. The World Bank, Washington DC.

Pinto, F.; Marques, R. (2015a), 'Tariff recommendations: A panacea for the Portuguese water sector?'. Utilities Policy, 34, 36-44.

Pinto, F.; Marques, R. (2015b), 'Tariff structures for water and sanitation urban households: a Primer'. Water Policy, 17(6), 1108-1126.

PPIAF (2012) Lessons Learned from PPIAF Activities: Pricing and Affordability in Essential Services. Public Private Infrastructure Advisory Facility Note 8, March 2012.

Reed, B. (2005) Minimum Water Quantity Needed for Domestic Use'. WHO Technical Notes for Emergencies, 9, World Health Organization, Geneva.

Reynaud, A. (2010) 'Private Sector Participation, Regulation and Social Policies in Water Supply in France'. Oxford Development Studies, 38(2), 219-239.

Reynaud, A. (2006), 'Assessing the impact of public regulation and private participation on water affordability for poor households: An empirical investigation of the French case'. LERNA Working Papers 06.09.202, LERNA, University of Toulouse.

Rietveld, P.; Rouwendal, J.; Zwart, B. (2000) ‘Block Rate Pricing of Water in Indonesia: An Analysis of Welfare Effects'. Bulletin of Indonesian Economic Studies, 36(3), 73-92.

Sawkins, J.; Dickie, V. (2005) 'Affordability of household water services in Great Britain'. Water and Environment Journal, 19, 207-213.

Smets, H. (2009) 'Access to drinking water at an affordable price in developing countries'. In: El Mou Jabber, M., Man di, L., Trisorio-Liuzzi, G., Martín, I., Rabi, A., Rodríguez, R. (eds.). Technological perspectives for rational use of water resources in the Mediterranean region. Bari: CIHEAM, 2009. p. 57 -68 (Options Méditerranéennes: Série A. Séminaires Méditerranéens; n. 88). 
Stern, J.; Mirrlees-black, J. (2012) 'A framework for valuing water in England and Wales'. Utilities Policy, 23, 13-30.

UNESCO (2015) Water for a sustainable world. The United Nations World Water Development Report 2015, United Nations Educational, Scientific and Cultural Organization, Paris.

Wang, H.; Xie, J.; Li, H. (2010) 'Water pricing with household surveys: A study of acceptability and willingness to pay in Chongqing, China'. China Economic Review, 21(1), 136-149.

Whittington, D.; Nauges, C.; Fuente, D.; Wu, X. (2015) 'A diagnostic tool for estimating the incidence of subsidies delivered by water utilities in low-and medium-income countries, with illustrative simulations'. Utilities Policy, 34, 70-81.

Worthington, A.; Hoffman, M. (2008) 'An empirical survey of residential water demand modelling'. Journal of Economic Surveys, 22(5), 842-871.

Xu, K. (2005) 'Distribution of health payments and catastrophic expenditures: Methodology'. Discussion paper n. 2, World Health Organization, Geneva. 